\title{
Kriittinen pedagogiikka tiedusteluretkellä Suomessa
}

Henry A. Giroux \& Peter McLaren (2001). Kriittinen pedagogiikka. Suom. Jyrki Vainonen. Toim. Tapio Aittola \& Juha Suoranta. VASTAPAINO

\section{Opiskele perusasiat!}

Jos aloitetaan perusasioilla, näyttäisi "maailman tilan" yleiskuva jokseenkin seuraavalta Amerikoista päin katsoen: elintason ja elämänmuotojen kuilut saavuttavat uusia mittasuhteita ja tuottavat hyvinvoivan kansanosan omahyväisyyden, jonka ylittämiseksi pienetkin eettiset ja ekologiset edistysaskeleet vaativat valtavia ponnistuksia; taloudellisesta röyhkeydestä ja konsumeristisesta hedonismista tehdään poliittisesti tuettua ja ekonomisesti toivottua, kansantalouden kasvua takaavaa uutta kansalaismoraalia; energiankulutuksen kiihdyttäminen asetetaan kansallisen menestyksen ennakkoehdoksi, jonka rinnalla vaakakupissa yhden planeetan tulevaisuus ei paljon paina; menestyneet ja keinoja kaihtamattakin vaurastuneet yksilöt katsovat oikeudekseen moralisoida vastuullisen ja itsenäisen ihmisen ihanteilla eli ideologialla, jolla käytännössä tuotetaan menestymisen mahdollisuuksia säätelevää fatalismia ja ruokitaan vallitsevaa eriarvoisuutta; koulutuksessa kyvykkyyden, lahjakkuuden ja "exellenssin" ylevöittäminen peittää alleen sen realiteetin, että vielä syntymättömienkin lasten menestymisen mahdollisuudet ratkaisee 1) ihonväri,
2) sosiaaliluokka, 3) vanhempien tulotaso, 4) syntypaikka, 5) asuinkortteli. Yms.

\section{Niinpä: jos katsotaan,}

minkälainen poliittinen agenda on saanut hyväksynnän maailman vaikutusvaltaisimman valtion äänestyshalukkailta (tai -kyvykkäiltä) kansalaisilta, ei tunnu kovin yllättävältä, että sen yhtenä vastareaktiona on yhteiskuntakriittisen kasvatusteorian radikalisoitumisen aalto vahvasti liikkeellä juuri Amerikassa. Suomessakin vieraillut kanadalaissyntyinen McLaren ja jenkki Giroux parantavat maailmaa sellaisella paatoksellisella ja koukeroisella kynäilyllä, joka ei lukijaa jätä kylmäksi, ei hyvässä eikä pahassa. McLaren tuli tunnetuksi Torontossa tekemillään kouluetnografi- 
oilla ja Giroux muistetaan ehkä erityisesti Stanley Aronowitzin kanssa kirjoittamastaan teoksesta Postmodern Education (1991), jossa pyrittiin osoittamaan aikakauden murroksellisuuden merkkejä ja haasteita koulutuksessa. Suomennoskokoelmassa heiltä julkaistaan yhteensä kuusi tekstiä 90-luvun varrelta. Ensimmäisissä artikkeleissa pyritään kriittisen pedagogiikan määrittelyyn ja kirjoittajien oman aseman täsmentämiseen, kolmas artikkeli käsittelee narratiivien merkitystä identiteettien rakentumisessa, neljäs moderni/postmoderni -keskustelua, viides nuorisokulttuurin kaupallistumista ja viimeinen opettajankoulutuksen tulevaisuutta. Tekstit ovat näin kohtuullisen kattava läpileikkaus Giroux'n ja McLarenin tuotannon viimekäänteistä.

\section{Yömajan mies, opiskele!}

Tiiviisti kirjoittajat kuvaavat omaa eetostaan näin: "Kriittistä pedagogiikkaa ohjaavien periaatteiden lähtökohtana on vakaumus siitä, että yksilön tai laajemman ryhmän yhteiskunnallisten mahdollisuuksien kasvattaminen on eettisesti ensisijaista tietoteoreettisiin tai markkinavoimien palvelukseen valjastettuihin teknisiin tai sosiaalisiin taitoihin nähden.” (s. 31) Tämä ei vielä kerro kovin paljoa tekstien sisällöstä, mutta tuo esiin niiden perusvireen. Kriittinen pedagogiikka ottaa kriittisten, autonomisten yksilöiden kasvattamisen kaiken kasvatuksen ylimmäksi päämääräksi ja sen jälkeen kritisoi johdonmukaisesti kaikkia harhautumisia tältä polulta. Kasvatuksen tehtävä on valmistaa yksilöitä kohtaamaan yhteiskunnalliset olosuhteensa, mutta ei 'pärjäämään' niissä vaan käsittämään niiden puutteellisuuden ja huomaamaan niissä piilevät utooppiset mahdollisuudet.

\section{Giroux'n ja McLarenin}

lähtökohdat ovat yhteisiä pohjimmiltaan hyvinkin erilaisille yhteiskunnalliseen kriittisyyteen sitoutuneille ja yksilöitä tai yhteisöjä valtauttamaan pyrkiville kasvatuksen teorian suuntauksille. Niitä voisi tyypitellä esim. seuraavasti. (1) On lähdettävä siitä, mikä on opiskelijoiden kannalta merkityksellistä: heidän elämismaailmastaan, kokemuksestaan, sosiaalisista tiloistaan, tavoitteistaan ja tarpeistaan. Muuten opetuksella ja siinä muodostettavalla tiedolla ei ole mielekästä kontekstia, johon se voi nivoutua. (2) On problematisoitava edellämainittuja yksilöllisiä elämäntiloja koskevien tulkintojen ja ennakko-oletusten 'luonnollisuus' ja pyrittävä osoittamaan, miten kyseiset tulkinnat ja merkitykset tulevat usein opiskelijoiden itsensä ulkopuolelta ja heijastavat vakiintuneita yhteiskunnallisia valtasuhteita. Yksilönkokemuksesta edetään yhteiskunnallisten suhteiden tarkasteluun, ja pyritään osoittamaan, millä tavoin yksityinen ja yleinen vaikuttavat toisiinsa. (3) Lopulta on luotava uskoa toimintamahdollisuuksiin, vaikuttamiseen, muutokseen ja ylipäätään murrettava käsitys, jonka mukaan tulevaisuus on jo fatalistisesti määrätty.

\section{Tätä projektia Giroux ja}

McLaren edistävät toisinaan suorastaan militantilla asenteella, joka silti reippaine ylilyönteineenkin on virkistävää luettavaa suhteutettuna suomalaiseen konservatiiviseen ja ylivarovaiseen kasvatuskeskusteluun. Kun meilläpäin esimerkiksi opettajien ja nuorisotyöntekijöiden yhteiskunnallisesta roolista puhutaan pienin kirjaimin ja kiertoilmauksin, ei tässä teoksessa vältellä aiheen poliittisia ulottuvuuksia. Juuret juontuvat selvästi Freiren kriittisestä pedagogiikasta, mutta pyrkimyksenä on päivittää sitä omaan aikaamme - mikä onkin suotavaa, kuten muistaa jokainen Freiren Sorrettujen pedagogiikan viimeisen luvun lukenut.

\section{Parhaiten kriittisen}

pedagogiikan amerikkalaisen muunnoksen sijainnista kasvatusteorian kentällä saa kuvan, jos ajattelee sitä tavoiterationaalista perinnettä (esim. Tylerin 'rationale') vastaan suunnattuna yhteiskuntakriittisenä opetussuunnitelmateoriana, jossa sitoudutaan radikaalin demokratian ihanteeseen ja Freiren kumouksellisen pedagogiikan perusajatuksiin, ja jossa problematisoidaan formaalin ja informaalin kasvatuksen rajaa. Neutraaleiksi esittäytyvät ja paikattomasti puhuvat opetussuunnitelmat ja -suunnittelumállit pyritään kontekstualisoimaan poliittisesti ja historiallisesti. Näkyville saatettujen valtasuhteiden oikeutusta pyritään horjuttamaan tukeutumalla mm. post-koloniaaliseen tai feministiseen kritiikkiin, brittiläiseen kulttuurintutkimukseen tai diskurssiteorioihin, poststrukturalismiin tai kriittiseen teoriaan. Lopuksi vaaditaan toivon palauttamista pedagogiikkaan, mm. vapautuksen 
teologiaan ja marxilaisiin utopiateoreetikoihin viitaten.

Kuten edeltävästä kuvauksesta voi jo päätellä, Giroux'n ja McLarenin omaa teoretisointia vaivaa kaikista hyvistä aikeista kasautuva viitekehysten ja teoriaperinteiden runsaus. Teksteissä luodaan yhä uudestaan panoptisia kuvia kaikesta siitä, mitä on ja mitä pitäisi olla, mutta liian harvoin pysähdytään analysoimaan todellisuutta rajattuja teoreettisia välineitä käyttäen, tavalla, joka veisi syvemmälle itse ilmiöihin. Kriittisen pedagogiikan erityisluonne ei myöskään kovin hyvin selkeydy teksteissä. Esimerkiksi positioimiseen tähtäävässä ykkösartikkelissa lasketaan kriittiseksi pedagogiikaksi lähes kaikki jollain tapaa yhteiskuntakriittinen kasvatusteoria, progressiivisesta pedagogiikasta marxilaisuuden ja reproduktioteorian kautta uuteen kasvatussosiologiaan ja postmoderniin ajatteluun. Kiinnostavaa on, että Giroux ja McLaren pyrkivät ottamaan etäisyyttä viimemainitusta, vaikka heidän asemansa kuvaukseksi se lienee kuitenkin kaikkein osuvin ${ }^{1}$.

\section{Tartu kirjaan nälkäinen, se on ase?}

Postmodernin teorian ankarimpia amerikkalaisia kriitikoita kasvatuksessa on ollut Richard A. Brosio, jonka mukaan postmodernismi ei ole kuin moneen käyttöön venyvää, myöhäisen kapitalismin kanssa hyvin yhteensointuvaa "kulttuurista pintaa", joka kätkee ja jättää koskemattomaksi yhteiskunnallisten valtasuhteiden ytimen. ${ }^{2}$ Kritiikki voi täsmätä moneen Amerikkalaiseen kirjallisuuden tai filosofian teoriatehtaaseen, mutta ei kovin hyvin osu postmodernin teorian kanssa liittoutuvien Giroux'n ja McLarenin teksteihin. Kokoelma osoittaa, että niissä on palattu yhä lähemmäksi 'perusasioita': kenellä on ja kenellä ei valtaa, rahaa, resursseja, toimintamahdollisuuksia, tulevaisuutta, toivoa. Kirjoittajat itse kritisoivat juuri postmodernia ja post-strukturalistista kritiikkiä siitä, että ne jäävät identiteettipolitiikan tasolle ja jättävät todellisten tuotantosuhteiden ja poliittisen vallan efektit tarkastelunsa ulkopuolelle. Kuka tahansa tajunnee, että yhä globaalimpi kapitalismi on tuonut mukanaan sellaisia uusia eriarvoistumisen ja alistamisen muotoja, joiden havaitsemiseen ja kritisoimiseen ei tarvita monimutkaista hermeneuttista välineistöä eikä hienovireistä kykyä lukea kulttuurisia koodeja.

\section{Paikoitellen kohdallisia}

ovat sen sijaan Alan Sadovnikin väitteet, joiden mukaan postmodernien teoreetikoiden tekstit ovat kielellisesti vaikeaselkoisia, usein kaukana käytännön kenttätyöstä ja puutteellisesti empiiristä tutkimusta hyödyntäviä. ${ }^{3}$ Tätä kuvaa vahvistaa teoksen kolmas artikkeli, joka ottaa narratiivisuuden analyysikäsitteeksi yrittäessään tuottaa valtauttavia identiteettipoliittisia mahdollisuuksia. Todellisuuden diskursiivisuuteen, tekstuaalisuuteen ja narratiivisuuteen palataan yhä uudelleen, vaikka toisaalta poliittisesti ja eettisesti vastuutonta postmodernia teoretisointia myös kritisoidaan ankarasti. Kirjoittajat valittelevat, että kriitti- nen kasvatusteoria on irtaantunut sekä empiirisistä ilmiöistä teorian juurissa että käytännön toimintamallien etsimisestä teorian sovelluksena, mutta sama ongelma tuntuu vaivaavan myös heidän omia tekstejään.

\section{Tekstien keskusteluyhteys}

ei aina lukijalle selviä. Esimerkiksi "Tällä hetkellä on vallalla kasvatuskäytäntö, jossa..." tai "viimeaikaiset yritykset..." (s. 73) - siis missä vallalla, kenen yritykset ja koska? Tekstien kommentoiva toimittaminen ja niihin liittyvien amerikkalaisten kiistojen esiintuonti olisi lisännyt paitsi tekstien ymmärrettävyyttä, myös niiden kiinnostavuutta. Kirjoittajat edustavat sitä vähäistä osaa sikäläisestä tiedeyhteisöstä, joka on todella ahkerasti osallistunut yhteiskunnalliseen keskusteluun, ja tämän keskustelun poliittisten ja akateemisten linjojen kuvaaminen johdannossa tai viitteissä olisi suuresti hyödyttänyt lukijoita. Sama pätee vasemmistolaisen kasvatusteorian sisäisiin rajakiistoihin. Amerikkalaiselle yliopistomaailmalle tyypillistä on suurten tähtien ja heidän ideoidensa 'tuotteistaminen', johon tekijät itse yleensä halukkaasti osallistuvat. Näillä imagomarkkinoilla ei useinkaan tarvitse lausua ääneen niitä tahoja, joista otetaan etäisyyttä tai joiden kanssa liittoudutaan. Kun Giroux ja McLaren kärkkäästi kritisoivat "perinteistä radikaalia kasvatuksen teoriaa" käy annetuista esimerkeistä ilmi, ettei kyseessä ole niinkään reproduktioteorian vanha kaarti Euroopassa tai USAssa vaan esimerkiksi perinteisempää marxilaisuutta edusta- 
vat kilpakumppanit Michael W. Apple ja Martin Carnoy. Kokoelma on siis monella tapaa vaikeaa ja haastavaa luettavaa. Kääntäjänkään tehtävä ei ole ollut helppo kirjoittajien rönsyilevän ja teoreettisella eklektismillä ladatun tekstin äärellä. Yhtenä ongelmana on tässäkin tapauksessa vakiintuneen suomenkielisen sanaston puute. Esimerkiksi "kulttuuripolitiikka" (cultural politics), jolla kirjoittajat viittaavat kulttuuristen käytäntöjen tavallisesti piiloiseen poliittisuuteen, jonka vaikutuksia koulutuksessa kriittinen pedagogiikka koittaa tuoda esiin, saa suomalaisen ajattelemaan ensimmäiseksi virkamiehiä ja "kulttuurin" hallinnointia (policy). Lukijaa olisi myös helpottanut joidenkin muualla akateemisessa kielenkäytössä jo vakiintuneiden termien säilyttäminen sivistyssanoina. Nyt useille postmodernin kritiikin viljelemille iskusanoille on kehitetty arkikielisempi kiertoilmaus. En tiedä hyödyttääkö tämä ketään. Joissain kohdin suomentamispyrkimys saa aikaan harhautuksia - esimerkiksi jonkin ilmiön 'problematisointi' (to make problematic) ei läheskään aina tarkoita sen "kyseenalaistamista", "mahdollisuuksia luova" ei aina vastaa 'valtauttavaa' (empowering).

\section{Tavoitteena on varmasti}

ollut tehdä kirjasta maallikoille ymmärrettävämpi, mutta Giroux'n ja McLarenin teoretisointi on siinä määrin lennokasta ja koukeroista, että tavoite ei vielä sivistyssanoja välttelemällä toteudu. Kirjan puutteeksi jääkin, että siihen perehtyminen vaatii aiempaa kohdallista teorian tuntemusta, eikä se näin ehkä riittävästi puhuttele arkityössään ahertavia opettajia, eikä anna heille kouriintuntuvaa kättäpidempää.

\section{Vorwärts!}

Mutta missäpä ei olisi puutteita? Ainakin viimemainittu puute on mahdollista paikata joko kääntämällä lisää kriittistä pedagogiikkaa tai tuottamalla Giroux'n ja McLareninkin viitoittamaa teoreettista kehystä hyödyntäviä tutkimuskokoelmia kotimaisin voimin. Tästä syystä nyt käännettyä kokoelmaa ei vielä voi kutsua kriittisen pedagogiikan maihinnousuksi - olkoon se pikemminkin maaston tunnustelua. Toisaalta pitää muistuttaa, että kriittisen kasvatusajattelun muodot elävät omilla tavoillaan ja omilla nimillään Suomessakin, itsenäisesti ennen ja ilman "kriittisen pedagogiikan" brändimerkkiä - eikä ole mitään syytä ryhtyä kytkemään kasvatuksellista kriittisyyttä yhden kieliopin puitteisiin.

\section{Jatkotoiveille jättää}

varaa myös se, että kriittinen pedagogiikka lanseerataan Suomeen tässä vain kahden, vieläpä sen postmodernia laitaa edustavan amerikkalaisen teoreetikon kautta. Kirjoittajat ovat toki tunnettuja alallaan, mutta kuitenkin vain yksi osa laajaa liikehdintää.

Kokoelman koostaminen useamman kirjoittajan teksteistä olisi perusteltua, vaikka edelleen rajauduttaisiin vain englanninkieliseen kirjallisuuteen, ja jätettäisiin huomiotta esimerkiksi kriittisen teorian nykysovelluksiin perustuvat saksalaiset suuntaukset.
USA:sta kannattaisi noteerata vaikkapa Michael W. Apple sekä opetussuunnitelmateorian radikaalia uudistamista ("reconceptualization") edistänyt William F. Pinar, jotka molemmat ovat aloittaneet tuotantonsa jo 70-luvulla. Muitakin kääntämisen arvoisia yhteiskuntakriittisiä teoreetikoita tai tutkijoita löytyisi amerikkalaisesta kasvatustieteestä Kincheloesta Wexleriin, puhumattakaan brittiläisistä koulutussosiologeista ja opetussuunnitelmateoreetikoista Bernstein, Young, Whitty, Jarvis, Kelly, Goodson, jne, jne. ${ }^{4}$

\section{Nimien listaaminen ei}

sinänsä kerro vielä mitään, mutta muistuttaa ainakin siitä, että suomennostoiminta kasvatustieteessä on ollut lähes olematonta, ellei lasketa eri lehdissä ilmestyneitä artikkelimittaisia käännöksiä. Osin tätä selittävät maakohtaiset erot koulutusperinteissä ja järjestelmissä, mutta muitakin syitä kannattaa etsiä, ja samalla miettiä sitä, miten tätä käännösflegmaattisuutta lääkittäisiin.

\section{Tuukka Tomperi}

\section{Viitteet}

1 Vrt. Pinar, W., Reynolds, W., Slattery, P. \& Taubman, P., Understanding Curriculum (Peter Lang, 1995).

2 Richard A. Brosio, A Radical Critique of Capitalist Education ( Peter Lang, 1994).

3 Ks. Ari Antikainen, Kasvatus, elämänkulku ja yhteiskunta (WSOY, 1998), s. 82.

4 Tosin juuri kuluvana vuonna ilmestyi Ivor F. Goodsonin kokoelma The Making of Curriculum Joensuu University Pressin kustantamana (ontuvalla) nimellä Opetussuunnitelman tekeminen. 